\title{
Gambaran Kadar Kolesterol Total Darah pada Mahasiswa Fakultas Kedokteran Universitas Sam Ratulangi dengan Indeks Massa Tubuh $\geq 23 \mathrm{Kg} / \mathrm{M}^{2}$
}

\author{
${ }^{1}$ Magdalena Talumewo \\ ${ }^{2}$ Murniati Tiho \\ ${ }^{2}$ Michaela E. Paruntu
}

\author{
${ }^{1}$ Program Studi Pendidikan Dokter Fakultas Kedokteran Universitas Sam Ratulangi Manado \\ ${ }^{2}$ Bagian Biokimia Fakultas Kedokteran Universitas Sam Ratulangi Manado \\ Email: magdalenatalumewo@gmail.com
}

\begin{abstract}
Unhealthy eating habit could lead to obesity. Obesity is always associated with the increase of blood cholesterol level (hypercholesterolemia). Increased cholesterol level is a risk factor of the death in young adult. This study was aimed to obtain the profile of total blood cholesterol levels among students of Faculty of Medicine Sam Ratulang University with body mass index $(\mathrm{BMI}) \geq 23 \mathrm{~kg} / \mathrm{m}^{2}$. This was a descriptive study. Samples were obtained by using total sampling method. There were 53 students involved in this study consisted of 22 males and 31 females. The results showed that 23 students $(43.4 \%)$ had normal total cholesterol levels and 30 students $(56.6 \%)$ had low total cholesterol levels. Conclusion: More than half of the students of Faculty of Medicine Sam Ratulangi University with BMI $\geq 23 \mathrm{~kg} / \mathrm{m}^{2}$ had low total cholesterol level.
\end{abstract}

Keywords: total cholesterol, $\mathrm{BMI} \geq 23 \mathrm{~kg} / \mathrm{m}^{2}$.

\begin{abstract}
Abstrak: Kebiasaan makan yang tidak sesuai dengan kaidah sehat dapat mengakibatkan obesitas. Kondisi obesitas selalu dikaitkan dengan peningkatan kadar kolesterol dalam darah atau hiperkolesterolemia. Peningkatan kadar kolesterol merupakan factor risiko penyebab kematian di usia dewasa muda. Penelitian ini bertujuan untuk mengetahui gambaran kadar kolesterol total darah pada mahasiswa Fakultas Kedokteran Universitas Sam Ratulangi dengan indeks massa tubuh (IMT) $\geq 23 \mathrm{~kg} / \mathrm{m}^{2}$. Jenis penelitian ialah deskriptif. Sampel diperoleh dengan metode total sampling. Penelitian ini diikuti oleh 53 orang subyek penelitian yang terdiri dari 22 orang laki-laki dan 31 orang perempuan. Hasil penelitian mendapatkan 23 orang $(43,4 \%)$ memiliki kadar kolesterol total normal dan 30 orang $(56,6 \%)$ memiliki kadar kolesterol total rendah. Simpulan: Lebih dari setengah mahasiwa Fakultas Kedokteran Universitas Sam Ratulangi dengan IMT $\geq 23 \mathrm{~kg} / \mathrm{m}^{2}$ memiliki kadar kolesterol total rendah.
\end{abstract}

Kata kunci: kolesterol total, IMT $\geq 23 \mathrm{~kg} / \mathrm{m}^{2}$

Kebiasaan makan yang tidak sesuai dengan kaidah sehat dapat mengakibatkan berbagai macam gangguan kesehatan. Kebiasaan makan yang tidak sehat dalam memilih jenis makanan juga dapat berdampak pada masalah kelebihan berat badan (overwight) dan berakhir pada obesitas. ${ }^{1}$ Obesitas dipengaruhi oleh peningkatan nafsu makan, dan peningkatan nafsu makan ini dipengaruhi oleh berbagai faktor. ${ }^{2}$

Obesitas merupakan masalah kese- hatan global dengan angka mortalitas dan morbiditasnya semakin meningkat. ${ }^{3}$ Obesitas merupakan faktor risiko kelima terbanyak yang menyebabkan kematian global. Sekurang-kurangnya 2,8 juta orang dewasa meninggal setiap tahun akibat obesitas. ${ }^{4}$ Kondisi ini dapat dialami oleh setiap golongan usia baik laki-laki maupun perempuan, akan tetapi remaja dan dewasa merupakan kelompok yang paling sering terjadi. ${ }^{5}$ Obesitas dipengaruhi oleh interaksi 
yang kompleks antara pola makan, faktor lingkungan, aktivitas fisik yang kurang, perilaku, dan genetik. $^{6}$

Indonesia merupakan negara berkembang yang seiring berjalannya waktu terjadi perubahan gaya hidup yang cukup signifikan dari tahun ke tahun. Hal tersebut berhubungan dengan peningkatan jumlah penyandang obesitas dari tahun ke tahun, dengan prevalensi obesitas pada usia dewasa yaitu $32,9 \%$ pada perempuan dan sebesar $19,7 \%$ pada laki-laki. Di Sulawesi Utara, prevalensi pada laki-laki $13,7 \%$ overweight, dan $14,3 \%$ obesitas. Pada perempuan $16,8 \%$ overweight, dan $29,5 \%$ obesitas. $^{7,8}$

Kondisi obesitas selalu dikaitkan dengan peningkatan kadar kolesterol dalam darah (hiperkolesterolemia) yang ditandai dengan kenaikan kadar kolesterol total, kolesterol low density lipoprotein (LDL) dan triasigliserol, serta penurunan kadar high density lipoprotein (HDL). Kondisi ini disebabkan karena penimbunan lemak pada keadaan obesitas akan menyebabkan sel adiposit tidak mampu menyimpan triasilgliserol secara adekuat, yang akan memicu kenaikan triasigliserol dan akhirnya kenaikan kadar LDL. Peningkatan kadar kolesterol darah dikaitkan dengan pembentukan plak aterosklerotik yang dapat menyumbat pembuluh darah, serta memicu serangan jantung dan stroke. ${ }^{9-11}$

Penelitian dari Hasrulsah dan Muhartono $^{12}$ mendapatkan adanya hubungan antara obesitas dengan keadaan hiperkolesterolemia. Dalam penelitiannya yang dilakukan pada sejumlah populasi berusia $>30$ tahun di Jawa Barat didapatkan adanya hubungan bermakna antara insiden obesitas dengan hiperkolesterolemia. Hasil penelitian menunjukkan bahwa $61,7 \%$ sampel mengalami obesitas dan $16 \%$ sampel mempunyai kadar kolesterol darah total yang tergolong hiperkolesterolemia.

Mahasiswa Fakultas Kedokteran cenderung mempunyai aktivitas fisik di luar kampus yang lebih rendah dari pada mahasiswa di Fakultas lainnya dan umumnya tidak mempunyai waktu untuk berolahraga. Hal ini dikarenakan setiap harinya maha- siwa Fakultas Kedokteran mempunyai jadwal kuliah yang cukup padat dari pagi sampai dengan sore hari. ${ }^{12}$

\section{METODE PENELITIAN}

Jenis penelitian ini ialah deskriptif dengan desain potong lintang. Pemilihan sampel dilakukan pada mahasiswa angkatan 2017 di Fakultas Kedokteran Universitas Sam Ratulangi Manado. Sampel dalam penelitian ini berjumlah 53 orang yang diambil dengan cara total sampling setelah memenuhi kriteria inklusi dan eksklusi. Pemeriksaan kadar kolesterol diambil melalui darah vena (fossa cubiti) oleh petugas laboratorium Pro-Kita Manado untuk diperiksa menggunakan alat $\mathrm{ABX}$ pentra 400.

\section{HASIL PENELITIAN}

Penelitian ini dilakukan untuk mengetahui gambaran kolesterol total darah pada mahasiswa angkatan 2017, dengan populasi berjumlah 65 orang. Total mahasiswa yang ikut sebagai subyek penelitian ini berjumlah 53 orang, sedangkan 12 orang lainnya tidak hadir saat pengambilan darah.

Karakteristik subyek penelitian berdasarkan jenis kelamin terdiri dari mahasiswa berjenis kelamin laki-laki berjumlah 22 orang $(41,5 \%)$ dan yang berjenis kelamin perempuan sebanyak 31 orang $(58,5 \%)$ (Tabel 1).

Tabel 1. Distribusi jumlah subyek penelitian berdasarkan jenis kelamin

\begin{tabular}{lcc}
\hline Jenis kelamin & Jumlah & \% \\
\hline Laki-laki & 22 & 41,5 \\
Perempuan & 31 & 58,5 \\
Jumlah & 53 & 100 \\
\hline
\end{tabular}

Karakteristik subyek penelitian berdasarkan status gizi, didapatkan subyek dengan status gizi overweight sebanyak 17 orang $(32,07 \%)$, obesitas I sebanyak 26 orang $(49,05 \%)$ dan obesitas II sebanyak 10 orang (18,86\%) (Tabel 2).

Berdasarkan hasil penelitian terhadap kadar kolesterol total dari 53 subyek penelitian didapatkan kadar kolesterol total yang normal sebanyak 23 orang $(43,4 \%)$ 
dan kadar kolesterol total yang rendah sebanyak 30 orang $(56,6 \%)$ (Tabel 3$)$.

Tabel 2. Distribusi jumlah subyek penelitian berdasarkan status gizi

\begin{tabular}{lcc}
\hline \multicolumn{1}{c}{ Status Gizi } & Jumlah & \% \\
\hline Overweight & 17 & 32,07 \\
23-24,9 & & \\
Obesitas I & 26 & 49,0 \\
$25-29,9$ & & \\
$\begin{array}{l}\text { Obesitas II } \\
>30\end{array}$ & 10 & 18,86 \\
Jumlah & 53 & 100 \\
\hline
\end{tabular}

Tabel 3. Distribusi jumlah subyek penelitian berdasarkan kadar kolesterol dalam darah

\begin{tabular}{lcc}
\hline $\begin{array}{c}\text { Kadar kolestrol } \\
\text { total }\end{array}$ & Jumlah & $\%$ \\
\hline $\begin{array}{l}\text { Normal } \\
(140-200 \mathrm{mg} / \mathrm{dL})\end{array}$ & 23 & 43,4 \\
$\begin{array}{l}\text { Borderline } \\
(200-230 \mathrm{mg} / \mathrm{dL})\end{array}$ & 0 & 0 \\
$\begin{array}{l}\text { Tinggi } \\
(>240 \mathrm{mg} / \mathrm{dL})\end{array}$ & 0 & 0 \\
$\begin{array}{l}\text { Rendah } \\
(<140 \mathrm{mg} / \mathrm{dL})\end{array}$ & 40 & 56,6 \\
Jumlah & 53 & 100 \\
\hline
\end{tabular}

Hasil laboratorium menunjukkan rerata nilai kadar kolesterol total darah responden ialah $140,43 \mathrm{mg} / \mathrm{dL} \pm 22,40$, dengan nilai minimum sebesar $93 \mathrm{mg} / \mathrm{dL}$ dan nilai maksimum sebesar $199 \mathrm{mg} / \mathrm{dL}$. Pada penelitian ini rerata IMT subyek penelitian ialah 28,9 $\mathrm{kg} / \mathrm{m}^{2} \pm 2,73$, dengan nilai IMT minimum sebesar $26,9 \mathrm{~kg} / \mathrm{m}^{2}$ dan IMT maksimum sebesar $32,3 \mathrm{~kg} / \mathrm{m}^{2}$.

\section{BAHASAN}

Hasil penelitian menunjukkan bahwa lebih dari setengah subyek penelitian memiliki kadar kolesterol total darah termasuk dalam kategori rendah, yaitu sebanyak 30 orang $(56,6 \%)$ dan subyek dengan kadar kolesterol total yang termasuk kategori normal terdapat sebanyak 23 orang $(43,4 \%)$.

Pada penelitian yang dilakukan oleh Gostynski et $\mathrm{al}^{13}$ terhadap 27 populasi dengan 48.283 subjek dan IMT 26 s/d 74 didapatkan bahwa populasi tersebut me- nunjukkan kadar kolesterol yang rata-rata rendah. Hal tersebut kemungkinan karena faktor penurunan aktivitas reseptor LDL, interaksi antar usia, pola hidup, dan factor lingkungan.

Alafanta ${ }^{14}$ melakukan penelitian dengan desain penelitian potong lintang mengenai pemeriksaan kolesterol pada penyandang obesitas yang berusia 30-60 tahun sebanyak 20 orang. Hasil penelitian menunjukkan bahwa sebanyak 7 orang (35\%) memiliki kadar kolesterol total tinggi, sedangkan 13 orang $(65 \%)$ memiliki kadar kolesterol total normal. Hal ini menunjukkan bahwa tidak selalu orang yang obes mengalami hiperkolesterolemia.

Penelitian lainnya dilakukan oleh Wongkar et $\mathrm{al}^{15}$ pada masyarakat di Kelurahan Bahu Kecamatan Malalayang Manado mengenai hubungan status gizi dengan kadar kolesterol total. Hasil analisis data 63 responden mendapatkan bahwa tidak terdapat hubungan antara status gizi dengan kadar kolesterol total pada masyarakat di Kelurahan Bahu Kecamatan Malalayang Manado.

Hiperkolesterolemia umumnya diderita oleh orang yang sudah lanjut usia atau orang obes tetapi tidak dapat menutup kemungkinan gangguan metabolisme ini dapat terjadi pada orang kurus bahkan usia muda. Menurut penelitian dari Malik et $\mathrm{al}^{16}$ mengenai gambaran kolesterol total darah pada mahasiswa angkatan 2011 Fakultas Kedokteran Unsrat dengan IMT 18,5-22,9 $\mathrm{kg} / \mathrm{m}^{2}$ dari 31 mahasiswa didapatkan kolesterol total dalam ambang batas tinggi sebanyak 8 orang $(25,8 \%)$.

Penelitian yang dilakukan oleh Listiana et al $^{17}$ mengenai kadar kolesterol total pada usia 25-60 tahun dengan 30 sampel mendapatkan bahwa terdapat hubungan bermakna antara kadar kolesterol total dengan usia. Hal ini dikarenakan pada usia yang semakin tua, kadar kolesterol total akan lebih tinggi, yang menunjukkan bahwa usia dapat memengaruhi kadar kolesterol total seseorang. Semakin tua usia, maka kadar kolesterol totalnya relatif lebih tinggi dari pada kadar kolesterol total pada usia muda karena makin tua seseorang 
aktifitas reseptor LDL mungkin makin berkurang.

Hasil penelitian dari Listyana et $\mathrm{al}^{18}$ mengenai pemeriksaan kadar kolesterol total darah pada obesitas sentral mendapatkan bahwa dari 81 orang subyek penelitian, sebagian besar mempunyai kadar kolesterol darah total termasuk dalam kategori normal, yaitu sebanyak 46 orang $(56,8 \%)$ sedangkan kadar kolesterol darah total yang termasuk kategori perbatasan hingga tinggi sebanyak 22 orang $(27,2 \%)$ dan kategori hiperkolesterolemia sebanyak 13 orang (16\%). Subyek penelitian mempunyai kadar kolesterol darah total dalam kategori normal dikarenakan konsumsi kolesterol dalam kategori baik dan sebagian subyek teratur berolahraga.

Hasil penelitian yang dilakukan oleh Mushtag et $\mathrm{al}^{19}$ pada 40 subjek yang terdiri dari 30 obes dan 10 non-obes melaporkan bahwa kadar kolesterol total darah lebih tinggi pada subjek yang obes dibanding non-obes.

Limitasi penelitian ini ialah respon rate dalam penelitian ini hanya sebesar $81,5 \%$. Selain itu tidak dilakukan pengambilan data mengenai daily food record, sehingga tidak ada data tentang jumlah kolesteroleksogen yang dikonsumsi setiap hari.

\section{SIMPULAN}

Berdasarkan hasil penelitian ini dapat disimpulkan bahwa lebih dari setengah mahasiwa angkatan 2017 Fakultas Kedokteran Universitas Sam Ratulangi dengan IMT $\geq 23 \mathrm{~kg} / \mathrm{m}^{2}$ memiliki kadar kolesterol darah rendah.

\section{SARAN}

Disarankan kepada subyek penelitian yang memiliki kadar kolesterol total darah rendah dan normal agar selalu menjaga kadar kolesterol total dalam batas normal (140-200 mg/dL) dengan cara mengatur pola makan, berolahraga secara teratur, dan menghindari faktor-faktor risiko yang dapat menyebabkan hiperkolesterolemia.

Diperlukan penelitian lanjut dengan variabel penelitian yang lain, misalnya, hubungan pola makan dengan kejadian hiperkolesterolemia.

Ucapan terima kasih ditujukan kepada mahasiswa angkatan 2017 di Fakultas Kedokteran Universitas Sam Ratulangi, Laboratorium Klinik Pro-Kita, dan semua pihak yang ikut terlibat dalam penyelesaian tulisan ini.

\section{DAFTAR PUSTAKA}

1. Sudoyo AW, Setiyohadi B, Alwi I, Simadibrata M, Setiati S. Buku Ajar Ilmu Penyakit Dalam (5th ed). Jakarta: Pusat Penerbitan Departemen Ilmu Penyakit Dalam FK UI, 2009; p. 197383.

2. Nelson, Behrman, Kliegman, Arvin. Ilmu Kesehatan Anak Nelson Vol. 1 (15th ed). In: Pendit BU, editor. Jakarta: EGC, 2000; p. 466-75.

3. National Obesity Observatory. International comparisons of obesity prevalence, 2015.

4. Hamdy O. Obesity. [ Internet ] Last update 2012 September [cited 2017 Sept 25]. Available,from:mhttp.://emedicine.med scape.com/article/123702-overview

5. Handoyo, Rohadi P. Hubungan obesitas, dengan risiko obstructive sleep apnea (OSA) pada remaja. Jurnal Ilmiah Kesehatan Keperawatan. 2012;8:1.

6. Supeni, Asmayuni. Kegemukan (Overweight) pada perempuan umur 25-50 tahun. Jurnal Kesehatan Masyarakat. 2007;II (1):111-5.

7. Kementerian Kesehatan Republik Indonesia. Gizi Seimbang, Bangsa Sehat Berprestasi. Available from: www.depkes. go.id.Jakarta.2014.

8. Riset Kesehatan Dasar, RISKESDAS. Laporan Hasil Riset Kesehatan Dasar, Jakarta; RISKESDAS, 2010.

9. Dorland WAN. Kamus Kedokteran Dorlan (29th ed). In: Hartanto $\mathrm{H}$ et al, editors. Jakarta; EGC, 2002; p. 1041.

10. Marks DB, Marks AD, Smith CM. Metabolisme kolesterol dan lipoprotein darah. In: Pendit BU, editor. Biokimia Kedokteran Dasar. Jakarta: EGC, 2000; p. 513-32.

11. Hasrulsah B, Muhartono. Hubungan obesitas dengan kolesterolemia pada pasien usia $>30$ tahun. Jurnal Kedok- 
teran Unila. 2012;1(1):111-20.

12. Ranggadwipa D. Hubungan aktivitas fisik dan asupan energi terhadap massa lemak tubuh dan lingkar pinggang pada mahasiswa Fakultas Kedokteran Universitas Diponegoro [Skripsi]. Semarang: Universitas Diponegoro; 2014.

13. Gostynski M, Gutzwiller F, Kuulasmaa K, Doring A, Ferrario M, Grafnetter D, et al. Analysis of the cholesterol, age, body mass index among males and females in the WHO MONICA Project. Int J Obes Relat Metab Disord. 2014; 28:1082-90

14. Alafanta I. Pemeriksaan kolesterol pada pasien obesitas yang berusia 30-60 tahun di RSUP Hj Adam Malik Medan [Karya Tulis Ilmiah]. 2011.

15. Wongkar MC, BJ Kepel, Hamel RS. Hubungan status gizi dengan kadar kolesterol total pada masyarakat di
Kelurahan Bahu Kecamatan Malalayang. e-Kp. 2013;1.

16. Malik MA, Mewo YM, Kaligis SHM. Gambaran kadar kolesterol total darah pada mahasiswa angkatan 2011 Fakultas Kedokteran Univesitas Sam Ratulangi dengan indeks massa tubuh 18,5-22,9 $\mathrm{kg} / \mathrm{m}^{2}$. eBM. 2014;1(2): 1008-1013.

17. Listiana L, Purbosari TY. Kadar kolesterol total pada usia 25-60 tahun. Jurnal Kesehatan. 2006:5(1):36-40.

18. Listiyana AD, Mardiana, Prameswari GN. Obesitas sentral dan kadar kolesterol total darah. Jurnal Kesehatan Masyarakat. 2013;9(1):37-43.

19. Mushtag R, Mushtaq R, Akram A, Khwaja S, Ahmed S. Study of serum cholesterol level in adult obese population of Karachi, Pakistan. OJEMD. 2014;4:238-43. 